\title{
Levy oration \\ Ideas, innovation and resilience
}

PAT GARDEN

I'm honoured and humbled to have been asked to present the inaugural Levy Oration. Sir Bruce Levy not only made a huge impact as an evangelist for grassland farming during his working life but his influence and legacy is as relevant as ever to the basic tenets of growing grass in a modern world.

I'd like this morning to first take you back on a brief journey in time to look at how the grassland industry developed as seen through the eyes of a hill country farmer; then to take stock of where we are now in 2012. And finally with a crystal ball tucked under one arm and a sharp stick to prod and provoke in the other, take a look out into the future.

When I started farming in 1961 I hadn't heard of Bruce Levy. My parents had insisted (to all their seven children) that once University Entrance was achieved, we were free to leave high school and head in whatever direction we chose. When I arrived home to the small 200 ha family farm in Moa Flat, full of youthful ideas and enthusiasm, excited about a farming future, and argumentative into the bargain, my father took a very interesting approach to dealing with this 17-year-old. Right at the outset, he said to me "Ok, Pat, you're in charge - I'll tell you whether I think your decisions will work or not, but you have the final decision." Of course he knew that I didn't want to make a fool of myself and the operation was unlikely to run off the rails but the combination of youthful exuberance steadied by his knowledge and years of experience made for a marvellous working relationship which I still treasure. That lesson in the value of transferring responsibility in a way which gives youth its head but acknowledges experience remains a challenge for our industry, particularly as the age of farmers creeps up.

My thoughts of going on to Lincoln or Massey were put to one side as the excitement of responsibility took root, so I didn't learn about Levy or the other pioneers of the industry, at least not in an academic context. But at the practical level the findings from their science and their insights were permeating the grassland industry and helping to shape its growing success and importance. We were soon to leverage those advances in the next stage of the family's journey.

It was clear the 200 ha Moa Flat farm was never going to support the three boys who wished to go farming, so in 1965 a partnership of our father, myself, and my brother Eoin who had also not long left school, bought
Avenel, an extensive hill country property situated on the Lammerlaw Range above Millers Flat. (And in passing, a grateful salute to the State Advances Corp which gave low interest loans to young first-time farmers.)

The timing could not have been better! Avenel had been managed as a traditional pastoral operation corriedale wethers on the high country, large blocks and stocking based on seasonal changes. Many of the lowland grassland farming technologies so vigorously promoted by Levy such as the use of superphosphate, subdivision, rotational grazing and the use of selectively bred ryegrass and white clover were sitting waiting in the wings to be applied to hill country systems. When they were combined with the emerging innovations of aerial topdressing and electric fencing, they drove a revolution in the way these enterprises operated.

However, advances in science and technology were not the only drivers of progress and production increases, and I'd like to spend some time looking at ways in which ideas are transferred and new approaches explored. I am a great believer in the value farmers can get through learning from each other, and if outside expertise is included in the mix, so much the better.

A number of focussed discussion groups operated in our valley during this period including a Farm Forestry discussion group, a Conservation group, a Share Investment group and the Farm Discussion group. I have been involved with them all, but the Millers Flat Farm discussion group was the single biggest influence in terms of innovation, benchmarking and maintaining enthusiasm. It included some articulate and forthright members, so putting a case up for group appraisal could be a stimulating process! However the response by the group was always tailored to the particular member submitting ideas - if he lacked a bit of confidence and was retiring by nature he was treated gently, but if he had a thick skin and was always offering advice, there were no holds barred and discussion became quite heated. Fortunately we had a series of astute convenors who managed the sometimes volatile mix very ably. It met monthly over a period of 25 years and offered both a provocative environment and a welcome social outlet. It was indeed a marvellous model for the transfer of ideas.

Shortly after we had been on the property, a couple of adjacent blocks came up for sale and were purchased in the name of the third brother Alan. Subsequently the partnership between me and my brother Eoin 
was dissolved and Avenel was split between the both of us. This meant the three brothers were farming independently but side by side on roughly equal areas of around 2300 ha. We all use the same genetics for both sheep and cattle, we farm in identical environments so any differences in outcomes are solely the result of different management decisions. There's no way to excuse poorer outcomes - if the system hasn't measured up, you stuffed up! We are all pretty competitive and the benchmarking that we are able to do against one another means we are constantly striving to do it better next time.

The next generation is now establishing itself on the three properties much to their respective parents' delight, particularly as the three cousins get along well with each other and appear to be using each other's particular skills to lift their own game. It's not a model that is readily transferrable to other neighbouring farmers, but its power to generate continual improvement is tremendous.

So what does the future hold for these young fellas and their families? Does hill country sheep and beef have an attractive outlook or will they need to augment their incomes by using some of the skills they developed before coming back on to the Lammerlaws?

Is the opportunity for innovation - in science as well as on farm, as great as it was during my farming lifetime, or has all the low hanging fruit been picked and they will be left with improving things around the margins? And what about the impact of public opinion on our livestock and land operations? What global forces are at work?

Let's step back from the coalface and take a look at the big picture. I'm an optimist so I'll start with the positives. It's a commonly repeated story these days, but global population growth, rising Asian affluence, shrinking fresh water reserves and an increasingly volatile climate all point to a rosy future for a reliable food producer who can deliver safe products.

We have an abundant water supply and a marvellous grass growing climate. We have excellent infrastructure and skilled, innovative people.

Our reputation for producing safe foods is unparalled and we are the acknowledged experts in the management of grassland-based livestock systems with a hugely valuable bank of information and knowledge, both practical and scientific.

But these are complex and risky times and against that backdrop of wonderful opportunity there are some real threats emerging.

The most concerning global issue is the debt crisis with real potential for increasing social unrest and the resultant instability. Some commentators argue that Greece will eventually default and that the Eurozone will break up. There is a fundamental structural problem in the EU where member states are tied to a common currency unit - the Euro, but they are not tied to common taxation, pension or treasury functions. That might be $\mathrm{OK}$ if work ethics and competitiveness were matched across all states, but they are not, and it is placing the EU under huge stress. The system may struggle through but it is hugely uncertain. One thing that is for certain is that slowing or stagnant growth within our trading partners will surely impact on our returns.

\section{Biosecurity}

PSA in kiwifruit is a stark reminder that breaches in our system can occur.

Such an incursion in our livestock industry would be devastating.

\section{Currency risk.}

Notwithstanding the very high levels of foreign debt and our balance of payments deficit that are features of our economy, our exchange rate remains stubbornly high, severely compromising the profitability of our livestock enterprises.

One very interesting correlation is that if you chart the NZUS\$ crossrate over the last year and compare it with the chart of the S\&P 500 they track each other with remarkable consistency. This seems to emphasise that our currency is closely connected to the global market's perception of risk. As the appetite for risk goes up or down, so does our exchange rate with the US\$. What is surprising is that during this period of doom and gloom about the global financial crisis, the US sharemarket (along with the NZ\$) has risen steadily. Between the 31st May and 31st October 2012, the S\&P 500 has risen around $10 \%$ while the NZ\$ has risen just over $9 \%$

\section{Climate change.}

If one took the views on climate change as expressed in the New Zealand farming press as indicative of farmer opinion, I am certainly out of step with my peers. It might not be fashionable in farming circles but it is my strongly held belief that climate change is alive and well, it is almost certainly caused by human activity and it is largely irreversible. Few if any scientific bodies of national or international standing disagree with this view and it is the sheer weight of supporting scientific evidence which persuades me.

But within the public mind there is still a lot of doubt, and while they may be in the minority, there are also good scientists who dispute the general scientific consensus. On top of that, politicians world wide are reluctant to take a hard line over reducing emissions from fossil fuel for fear of driving their economy into an even deeper recession. The price of carbon credits has plummeted, tree planting has stalled, and the public has wearied of a steady diet of an Armageddon just around the corner. It is a jungle of claim and counter claim, public apathy and political inaction. To make any 
real impact all nations would have to commit to much more stringent energy policies, and frankly I don't see it happening any time soon. The commitment at Copenhagen to limit the temperature rise to within $2^{\circ} \mathrm{C}$ is most unlikely to be delivered.

The uncertainties in $\boldsymbol{m y}$ mind are not about what is happening, it's about what the impacts will be, particularly around increased frequency and severity of droughts and floods and how should we prepare ourselves to deal with those events. In a parochial sense, this southern area of the country could very well benefit from a longer growing season and warmer temperatures, but if I could be a fly on the wall in 30 years time I might very well hear those three cousins reminiscing to their children about to continue with farming on the Lammerlaws and saying "You know in our day we didn't have to contend with facial excema, kikuyu and black beetle..." In the meantime, I have taken a deliberate strategy to steadily develop the country between 650 and $1000 \mathrm{~m}$ altitude on Avenel as a future buffer against drought.

That's my take on the global issues confronting us out into the future, but what about down on the farm? One of the big changes that is starting to occur and will increase is that the customer is effectively sitting on our shoulder watching what we are up to as we operate our enterprises. Farm assurance programmes are getting more and more specific particularly around animal welfare and nutrient management. Audit, documentation and a huge increase in record keeping is a reality.

Compliance and regulation around the management of the environment, particularly water quality and soil retention on slopes, is creating a great deal of tension. As a general principle, if water quality is compromised as it flows through a property, then management should address that issue - achieving an appropriate balance between production and a healthy environment is a goal we all seek. But what constitutes a healthy environment, and if caps on production are to be imposed, how will the cost to the individual and to the community be dealt with? Will the consumer pay for the environmental cost?

I believe the realities of the global food supply, which is confronting even greater environmental challenge, offers some real hope. But the journey for land managers is going to be a challenging, a costly, and for some a very stressful process.

To stay in business the bottom line has to be maintained or improved, and in farming which buys retail and sells wholesale, that is difficult. With inflation of our cost structures a given, what potential is there for steadily increasing productivity, and by that I am referring to the ratio of outputs to inputs? Or in simple terms, can we maintain our profitability?

If we look at the output side, we've done pretty well over the last two decades. During that period, weight of lamb carcase/ewe wintered rose $89 \%$ from $9.3 \mathrm{kgs}$ to $17.6 \mathrm{kgs}$, milksolids/cow rose $29 \%$ from $260 \mathrm{kgs}$ to $334 \mathrm{kgs}$, but during the same period the dairy herd increased $72 \%$ - the combination of the two giving a huge increase in total milk solids production. It is unlikely that we will be able to sustain that rate of gain over the next two decades. As lambing percentages rise, for example, the increasing proportion of triplets and quads places an added burden on management inputs, while lamb carcase weights are approaching the market optimum. Improved genetics both in terms of improved performance and better feed conversion are certainly possible, improved feed utilisation offers a huge leap in efficiency, but the big gains we have made will inevitably flatten out.

Another graph courtesy of The Economic Service of Beef + Lamb NZ called the Total Factor Productivity Index looks at the relationship between inputs and outputs in both sheep and beef, and in dairy. It includes the opportunity cost of capital invested and is calculated on constant prices. The index shows sheep and beef trending upwards which is very positive, while dairy since 2007 is largely down. The big difference here is that sheep and beef carry around $80 \%$ equity, while dairy is around $53 \%$ equity.

So there is certainly potential for continued efficiencies for these three young families looking into their future. What about big new ideas and innovation? Can they continue to boost viability as they did for my generation through the insights of the Bruce Levys of the grassland world, or are new ideas and new insights harder and harder to find.

While you ponder that, let me take you back to the mid-eighties. A group of wives in our valley decided to start up a share club. It was in the heyday of the investment boom and everything they touched turned to gold. We husbands looking jealously over their shoulders, decided that we should set up the men's version and with our superior knowledge in matters financial we would show them how to really make money. Then about a year down the track the women decided out of the blue to sell everything up and go as a group on a trip to Australia - husbands as well I might add. Of course we men laughed behind their backs thinking now we'll catch up. Except that three weeks later the share market crashed and the men were left holding a lot of very expensive but worthless paper. The two groups still meet monthly and still have a great deal of friendly banter between them, but if we men get too uppity we are quickly reminded who are the canniest investors!

Some time later we men decided to do away with a full service broker and take a much more international approach to investment. We opened an on-line brokerage account in the US, bought an investment newsletter focussed on global stocks and away we went. We bought 
Chinese fertiliser companies and hotel chains, Indian banks, Latin American banks South American fast food franchisors, infrastructure and energy companies and US technology companies. Some were winners some were not but the real return was what we learnt about global business. One of the insights was the dynamic nature of innovation particularly in the US and how some ideas were so disruptive they turned the market on its head and became blockbusters. Amazon, Google and Apple under that genius Steve Jobs are great examples of the power of innovation and its potential to drive business models which generate unbelievable wealth.

So one could be excused for believing that invention and innovation are the twin engines that power an economy, that they are a given into the future and will remain a steadily running fountain from which to drink. But what if innovation follows that bastion of economic theory, the law of diminishing returns?

There is a very interesting paper on innovation called Complexity and the Productivity of Innovation by Strumsky, Lobo and Tainter which questions the assumption that innovation will continue to provide solutions to the problems we face. The US based team used patents as a stand in for innovation and inventiveness and looked at the number of patents/ inventor and the number of patents for a given amount of GDP over time. Even in fields such as nanotechnology and biotechnology, the trend moves down over time. They argue that fields of research follow a characteristic development pattern from general, to specialised and narrowly useful, from simple to complex, and as innovation grows more complex and costly it delivers diminishing returns. It is encapsulated in that lovely line from Lewis Carroll written in 1872 "Now, here, you see, it takes all the running you can do, to keep in the same place. If you want to get somewhere else, you must run at least twice as fast as that!"

So has my generation been the lucky ones living through the heyday of the grassland industry, driven by that simple recipe from Levy - sow improved species, fertilise them and wind up the fertility cycle by good grazing pressure? Will those three young families from the Lammerlaws have to resign themselves to small incremental doses of innovation barely sufficient to allow them to remain ahead of inflation?

I am much more optimistic than that! First, I think that focusing on patents is limiting in terms of defining innovation as it assumes only the new and original is eligible. Integration of known but apparently disparate ideas would be impossible to patent but may be highly innovative. Most importantly though the innovation described by Strumsky et al. describes a simple linear model where an inventor develops an idea, patents it and sells it to an end user market.

But Eric von Hippel in a classic book called Sources of Innovation argues that end user innovation is by far the most important and significant source of innovation. One of the critical components of end user innovation is what von Hippel terms "informal know how trading" which is essentially a pattern of informal cooperative $\mathrm{R} \& \mathrm{D}$. If we apply that to a farming context, our heritage of discussion groups, focus farms and monitor farm groups is a perfect fit. Our biological system, though, is a complex and variable beast, and to leverage the value of those structures, we need to add much more measurement and more data. Much of the comparisons we currently make are based on subjective information which is really only of interest value. We need to develop learning networks which bring together a range of skills and disciplines to complement the farmer's practical and commercial attributes. That for me is the model that needs to be nurtured as we head into the future.

So, let's recap:

- Global debt will slow economic activity for some time.

- As producers of quality food, we are in the box seat and will survive a global recession much better than most.

- We will face increasing climate volatility.

- The customer is king.

- Pressure to limit or cap production is not going to go away.

- Increasing efficiency is the new target.

Successful grassland enterprises will build resilience into their systems. That will mean less debt, targeting efficiency rather than maximising production, and developing their own learning networks which embrace experimentation and measurement. One thing that is certain is that the lessons Sir Bruce Levy so ably espoused will be just as relevant.

My final message is not about food or agriculture or declining resources - it's about nurturing our kids and our grandchildren. We need to constantly instil in them, a sense of curiosity and wonder - whether it's marvelling at an ever expanding universe or the overnight phenomenon of a mushroom dislodging a rock: we need to foster an ability to be objective, to see the other side of an argument as well as one's own shortcomings: and to have integrity.

The best way pull all that off is to lead by example.

\section{Acknowledgements:}

Rob Davison Economic Service, Beef + Lamb NZ Debbie Strumsky: "Complexity and the Productivity of Innovation". Strumsky, Lobo and Tainter.

Eric von Hippel: "Sources of Innovation" Barney Foran as a valued sounding board. 